NBER WORKING PAPER SERIES

\title{
CONSISTENT VALUATION AND COST OF CAPITAL EXPRESSIONS \\ WITH CORPORATE AND PERSONAL TAXES
}

Robert A. Taggart, Jr.

Working Paper No. 3074

NATIONAL BUREAU OF ECONOMIC RESEARCH

1050 Massachusetts Avenue

Cambridge, MA 02138

August 1989

I am grateful to Ivan Brick, Robert Dammon, Alan J. Daskin, James Miles, Lawrence Fisher, Abraham Ravid, Richard Ruback, Gordon Sick, Joseph Yagil and participants in the finance workshops at Boston University, the University of Delaware and Rutgers University of helpful comments on an earlier draft. I am, of course, responsible for any remaining errors. This paper is part of NBER's research programs in Taxation and Financial Markets and Monetary Economics. Any opinions expressed are those of the author not those of the National Bureau of Economic Research. 


\author{
NBER Working Paper \#3074 \\ August 1989

\section{CONSISTENT VALUATION AND COST OF CAPITAL EXPRESSIONS} \\ WITH CORPORATE AND PERSONAL TAXES
}

\begin{abstract}
This paper examines three valuation methods, each of which should lead to the same value for a given asset. These are the Adjusted Present Value, Adjusted Discount Rate and Flows to Equity methods. To achieve identical valuations, however, the different methods must be implemented with cost of capital expressions that embody a consistent set of assumptions about ( 1 ) the tax regime and (2) the time pattern and riskiness of debt tax shields. Valuation and cost of capital expressions that have been proposed in the literature are grouped and contrasted according to these assumptions. It is also shown that the familiar weighted average cost of capital can be consistent with any such set of assumptions, as long as the correct expression is used to estimate the relationship between the levered and unlevered cost of equity.
\end{abstract}

Robert A. Taggart, Jr.

Boston College

School of Management

Fulton Hall

Chestnut Hill, MA 02167 
The interaction between financing and investment is a classic problem in the valuation of firms and assets. If financing affects value, then an accurate estimate of value must take the financing mix into account. Recognition of this problem has in turn spawned a variety of methods for estimating asset value and the cost of capital, most of them focusing on the tax effects of financing.

This paper examines three basic valuation methods, each of which should lead to the same value for a given asset. These are the Adjusted Present Value, Adjusted Discount Rate and Flows to Equity methods. However, each method relies on a different cost of capital measure and incorporates the tax effects of financing in a different way. To achieve identical results, therefore, the different methods must be implemented with cost of capital expressions that embody a consistent set of assumptions.

The purpose of this paper is to group the different cost of capital expressions that have appeared in the literature according to consistent sets of assumptions. Specifically, it is shown that existing cost of capital formulas can be separated into six groups, depending on which of two tax regimes is assumed and which of three assumptions is made about the riskiness and time pattern of debt tax shields.' As long as the analyst works within one of these six groups, consistent results will be achieved using any of the three valuation methods.

The three valuation methods are described in more detail in Section I. Section II considers valuation with corporate but no personal taxes. The case in which a perpetual firm has a known, constant amount of debt outstanding is considered first, since this is the case that has been most frequently analyzed in the literature. It is then contrasted with the case in which future debt levels are uncertain. In Section III, personal taxes are introduced, and the equilibrium relationships between after-tax market rates of return are described. Cost of capital expressions are then derived under three different 
assumptions about the risk of future debt tax shields. The results are summarized, and conclusions are drawn in Section IV.

\section{Three Valuation Methods}

The three basic approaches to the valuation of companies or corporate assets each seek to discount after-corporate-tax cash flows at pre-investor-tax discount rates. The first of these is Myers'(1974) Adjusted Present Value, or APV method, the essence of which is to estimate value in two steps. First, a base-case value, under the assumption of $100 \%$ equity financing, is computed and then the costs and benefits of the actual financing package are added separately. The base-case value is calculated by discounting the asser's expected after-corporate-tax operating cash flows, $C_{n}$, for each period $n$ at an all-equity, or unlevered discount rate, $r{ }^{2}$ The appropriate discount rate for any additional terms, which involve financing costs or benefits, remains to be determined below, but in most applications the cost of debt has been used.

The second approach is the Adjusted Discount Rate, or ADR method. Here, expected operating cash flows, $C_{n}$, are discounted at a rate that reflects the assel's financing combination. Both the APV and ADR methods thus discount the same cash flows, but they adjust for financing in different ways. Under the APV method, the adjustment occurs in one or more separate discounted cash flow terms, while under the ADR method, the adjustment occurs entirely in the rate that is used to discount the operating cash flow stream.

The third approach is the Flows to Equity, or FTE method. Here, the equity value rather than the total value of the asset is calculated by discounting cash flows to the equityholders at a cost of equity capital. The cash flows are calculated by subtracting any after-corporate-tax financing charges, such as interest or lease payments, from the all-equity cash flows, $C_{n}$, and thus they represent actual cash flows to shareholders. By 
contrast, the cash flows used under the other two methods are hypothetical cash flows that the shareholders would receive if the asset were entirely equity-financed.

Under different circumstances, it might be more convenient to choose one of these valuation methods over the others. ${ }^{3}$ Nevertheless, all three are based on the same underlying theory of the valuation process, and if properly used, all three should yield identical results. We turn next to the issue of which cost of capital expressions are needed to ensure consistency across valuation methods.

A limitation of the analysis, which should be noted at the outset, is that all debt is assumed free of default risk. This assumption is made in part to maintain comparability with the bulk of the literature and in part to avoid unnecessary complexity. It does imply, however, that tax factors are the only effect of capital structure to be incorporated, while factors such as bankruptcy, agency and information costs are ignored. Some of the consequences of risky debt have been analyzed by Conine (1980), Myers and Ruback (1988), Sick (1988), and Yagil (1982).

\section{Valuation With Corporate But No Personal Taxes}

\section{A. The Case of Constant. Perpetual Debt}

The most familiar cost of capital expressions have been derived under the following assumptions: (1) corporations pay taxes at the rate $T_{c} ;(2)$ there are no personal taxes; (3) the amount of corporate debt financing is known and constant forever; (4) the firm's debt is free of default risk, so its cost of debt is $r_{f D}$, the required rate of return on riskless debt; and (5) the firm's expected operating cash flows are constant forever, so that $C_{n}=C$ for each period $n$. All of the notation used in this case and in the remainder of the paper is summarized in Table I.

Under these assumptions, the cost of capital and valuation expressions shown in Panel $A$ of Table II have been derived numerous times in the literature (e.g., Hamada (1969), Modigliani and Miller (1963), Rubinstein (1973), Taggart (1977)) and 
have been shown to give consistent results (Ashton and Atkins (1978), Chambers, Harris and Pringle (1982), Lewellen and Emery (1986), Myers (1974)) ${ }^{4}$. Equation (A1) embodies the Adjusted Present Value idea, in which the base-case value, $\mathrm{C} / \mathrm{r}$, is adjusted for the present value of the debt tax shield, $T_{c} D$. If, for example, $C=100, r=$ $.2, D=200$ and $T_{c}=.34, V=568$. The same value can be obtained under the Adjusted Discount Rate method by discounting $C$ using either of the expressions for $r^{*}$. With $D N$ $=.352$, Equation (A3), sometimes referred to as the $M M$ formula, yields $r^{*}=.176$, and

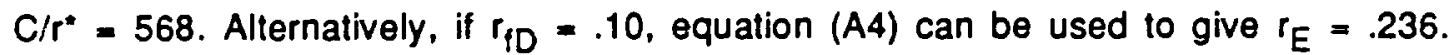
This value can in turn be used with Equation (A2), the weighted average cost of capital, to give $r^{*}=.176$ and $V=568$. The cost of equity can also be estimated using the capital asset pricing model (CAPM) approach, as in (A5). If we assume $r_{m}=.15$, then $\beta_{U}=2.0$ is consistent with $r=.20$. Equation $(A 6)$ then implies $\beta_{L}=2.72$, and from $(A 5), r_{E}=$ .236. Finally, under the Flows to Equity approach, equity value can be estimated directly by discounting the cash flows to the equityholders at the cost of equity, $r_{E}$. The cash flows to equityholders are equal to $\left(C-r_{10}\left(1-T_{C}\right) D\right)$, the after-tax operating cash flows minus the after-tax debt service. Discounting these cash flows, which equal 86.8 per year, at $r_{E}$ gives $E=368$.

The example illustrates that each of the three valuation methods yields consistent results using the cost of capital expressions in Panel A. The list of assumptions needed to ensure consistency is, of course, quite restrictive. In particular, since the operating cash flow stream is a level perpetuity and the amount of debt outstanding is constant, firm value also remains constant through time. This implies that the debt-to-value ratio is also constant, and thus it is immaterial whether debt is specified in dollar terms, as in (A1), or in ratio terms, as in (A2), (A3), (A4) and (A6). For an asset with a finite life, on the other hand, this distinction becomes important, since debt can no longer be constant both in dollar terms and as a fraction of asset value. This is the case considered by Miles and Ezzell $(1980,1985)$. 


\section{B. The Miles-Ezzell Analysis}

Miles and Ezzell (1980) started with the premise that the firm maintains a constant debt-to-value ratio. If current firm value is observable, the current debt level is known and, in the absence of default risk, the interest tax shield at the end of the first period is also known with cerlainty, since it is based on the current debt level. Thus it is justifiable to discount the first period's interest tax shield at $r_{\mathrm{fD}}$, the risk-free debt rate. Miles and Ezzell argued, however, that future firm values, and hence future debt levels, are currently uncertain. If the firm maintains a constant debt-to-value ratio, future firm value will be perfectly correlated with the value of the operating cash flow stream. Therefore, they reasoned, all interest tax shields beyond the first period should be discounted at $r$, the unlevered cost of capital.

Based on this reasoning, Miles and Ezzell $(1980,1985)$ derived the set of valuation and cost of capital expressions that appear in Panel C of Table II. Unlike the set of expressions in Panel A, the Miles-Ezzell expressions give consistent results for both perpetual and finite-lived assets. However, because of their different assumption about the risk of debt tax shields, these results will, in general, differ from those derived from Panel A, even in the perpetuity case.

Consider the numerical example of Section II.A., in which $C=100$ (forever), $r=$ $.20, T_{c}=.34, D N=.352, r_{f D}=.10, r_{m}=.15$ and $\beta_{U}=2.0$. Using the Adjusted Discount Rate method and Equation (C3) gives $r^{*}=.187$ and $V=534.9$. Or, using (C4) and (C2), $r_{E}=.253$ and again $r^{*}=.187$. Or, using $(C 6)$ and $(C 5), \beta_{L}=3.05$ and again $\mathrm{r}_{E}=.253$. Thus the expressions in Panel $\mathrm{C}$ yield results that are internally consistent , but different from those derived from Panel A. ${ }^{5}$ For the perpetuity case, the same results would be obtained from both panels only if all cash flows were riskless.

The essential distinction between the Miles-Ezzell approach and the approach embodied in Panel $A$ is the assumed time pattern and riskiness of the debt tax shields. Under the Miles-Ezzell approach, the debt-to-value ratio is held constant, so the risk of 
the debt tax shields depends on the risk of firm value itself. Miles and Ezzell argue that this risk is captured by $r$, the unlevered cost of capital. However, in the special case where the expected operating cash flow stream is a level perpetuity, the individual cash flows are risky but firm value is not. Each period's cash flow realization provides no new information about future firm value. Thus the approach in Panel $A$, which treats the dollar amount of debt as fixed and the interest tax shields from this debt as riskless, may seem more natural in this special case. In contrast, Miles-Ezzell is the more natural approach when each period's cash flow realization resolves some uncertainty about future firm value. In that case, future firm value is uncertain, and if a constant debtto-value ratio is to be maintained, the actual amounts of debt and hence the future interest tax shields become known only as this uncertainty is resolved.

Another point that emerges from contrasting Panels $A$ and $C$ is the role of the weighted average cost of capital, which can be used under either valuation regime. In effect, the market's valuation of debt tax shields is captured in the cost of equity, ${ }^{E}$. If the cost of equity is estimated in a way that correctly reflects investors' assumptions about the risk of the debt tax shields, whatever those assumptions may be, the weighted average cost of capital will yield a valid adjusted discount rate.

\section{Yaluation With Corporate and Personal Taxes}

\section{A. After-Tax Rate of Return Belationships}

When personal taxes are introduced, greater care must be taken in specifying investors' required returns. Required rates of return are often analyzed on a pre-tax basis, since these are more easily observable than after-tax returns. Nevertheless, it is after-tax returns that ultimately interest investors, and these will drive the equilibrium return relationships. It is useful to note at the outset, in fact, two such relationships that govern the pricing of debt and equity securities in this tax regime. 
In the remainder of this section, it is assumed that all investors pay taxes on income from debt securities at the rate $T_{p}$ and on income from equity securities at the rate $\mathrm{T}_{\mathrm{PE}}{ }^{6}$ for simplicity, it is assumed that all investors are subject to the same tax rates. In equilibrium, debt and equity securities of comparable risk must offer investors identical after-tax returns, since otherwise, investors would be motivated to rearrange their portfolios. In particular, suppose we have a risk-free debt security offering a pre-tax return per period of $r_{f D}$ and a risk-free equity security offering a pre-tax return per period of $\mathrm{rfE}^{7}$ These returns will be set in the market so that:

$$
r_{f D}\left(1-T_{P}\right)=r_{f E}\left(1-T_{P E}\right) .
$$

More generally, a tax-adjusted Capital Asset Pricing Model can be derived, as in Brennan (1970) and Gordon and Malkiel (1981), which characterizes the equilibrium after-tax returns on securities of both different risk and different tax treatment. Suppose, for example, that all risky assets are in the form of equity and that the expected pre-tax return to investors from the overall market portfolio of equities is $r_{m}$. Let ' ${ }_{E j}$ denote investors' pre-tax return on firm j's equity. It can then be shown that, in equilibrium, 8

$$
r_{E j}\left(1-T_{P E}\right)-r_{f D}\left(1-T_{P}\right)=\beta_{j}\left[r_{m}\left(1-T_{P E}\right)-r_{f D}\left(1-T_{P}\right)\right],
$$

where $\beta_{\mathrm{j}}$ is the usual measure of systematic risk. Using (1), the after-tax CAPM can also be expressed more simply as

$$
r_{E j}=r_{f E}+\beta_{j}\left(r_{m}-r_{f E}\right)
$$




\section{B. Valuation Under the APV Approach}

Consider first the Adjusted Present Value approach to corporate valuation in this tax regime. For the sake of generality, we analyze a finite-lived asset, treating perpetuities later as a special case. Starting at the end of the valuation horizon and working backward toward the present, suppose that the firm will pay a liquidating dividend to its shareholders at time $N$. This dividend consists of the after-corporate-tax operating cash flow, $\mathrm{C}_{\mathrm{N}}$, minus the after-corporate-tax payment of interest and principal on its beginning-of-period debt, $D_{N-1}$. Since the personal tax on equity income is levied against dividends plus capital gains, the beginning-of-period equity value, $E_{N-1}$, serves as a personal tax shield.

If we follow the certainty-equivalent approach, as used by Sick (1988), letting $C E O_{N}$ denote the pre-personal-tax certainty-equivalent of $\tilde{C}_{N}$, then the value of the firm's equity and debt at $\mathrm{N}-1$ can be expressed as:

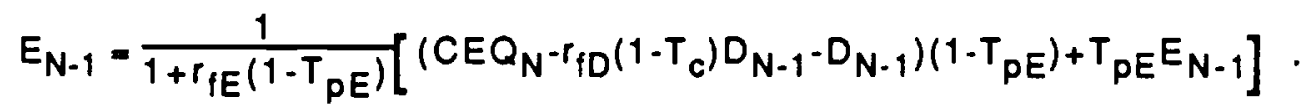

$$
\begin{aligned}
& D_{N-1}=\frac{1}{1+r_{f D}\left(1-T_{P}\right)}\left[r_{f D}\left(1-T_{P}\right) D_{N-1}+D_{N-1}\right]
\end{aligned}
$$

Noting from (1) that the two discount rates must be the same in equilibrium, we can combine (4) and (5) to determine $V_{N-1}=E_{N-1}+D_{N-1}$ :

$$
\begin{aligned}
& V_{N-1}\left(\left(1-T_{P E}\right)+r_{f E}\left(1-T_{P E}\right)\right)= \\
& \quad C E Q_{N-1}\left(1-T_{P E}\right)+r_{f D}\left(1-T_{p}\right)\left[1-\frac{\left(1-T_{C}\right)\left(1-T_{p E}\right)}{\left(1-T_{p}\right)}\right]_{N-1} .
\end{aligned}
$$


The expression in square brackets will be recognized as Miller's (1977) $G_{L}$, the net tax advantage to corporate debt. Dividing both sides of $(6)$ by $\left(1-T_{p E}\right)\left(1+r_{f E}\right)$ and using (1) then yields

$$
v_{N-1}=\frac{C E Q_{N}}{1+r_{f E}}+\frac{r_{f E} G_{L} D_{N-1}}{1+r_{f E}}
$$

We can iterate backward in similar fashion, but first an assumption must be made about whether future debt levels are certain or uncertain. If we assume, as has typically been done under the APV approach, that all future debt levels are known, it can be shown that for any period $t^{9}$

$$
V_{1}=\sum_{n=1+1}^{N} \frac{\operatorname{CEQ}_{n}}{\left(1+r_{f E}\right)^{n}}+\sum_{n=1+1}^{N} \frac{r_{f E} T \cdot D_{n-1}}{\left(i+r_{f E}\right)^{n}}
$$

The first term in (8) represents the firm's base-case value, or the value it would have if it were entirely equity-financed, while the second term represents the net tax benefit from corporate debt. In cases for which risk-adjusted discount rates are appropriate, (8) can also be written in the more familiar form ${ }^{10}$

$$
v_{t}=\sum_{n=1+1}^{N} \frac{c_{n}}{(1+r)^{n}}+\sum_{n=1+1}^{N} \frac{r_{f E} G_{L} D_{n-1}}{\left(1+r_{f E}\right)^{n}} .
$$

In either form, it is important to notice that the second term, the tax benefit from debt, involves the risk-free equity rate, not the risk-tree debt rate. This term is best thought of as the present value of an annual financing subsidy. As in Brealey and Myers (1988), for example, the value of a financing subsidy can be calculated as the 
present value of the annual difference between unsubsidized and subsidized debt service charges (after corporate taxes), discounted at the unsubsidized market rate (also aftercorporate-tax). In similar fashion, if we let $S$ represent the second term in (9), then (1) plus the definition of $G_{L}$ from Table 1 can be used to write $S$ as:

$$
S=\sum_{n=t+1}^{N} \frac{\left[r_{f E}-r_{f D}\left(1-T_{c}\right)\right] D_{n-1}}{\left(1+r_{f E}\right)^{n}}
$$

In words, a firm could in principle choose between two types of risk-free securities. It could issue risk-free equity at the rate $\mathrm{r}_{\mathrm{fE}}$, or it could issue debt at the tax-subsidized rate $r_{f D}\left(1-T_{C}\right)$. The net advantage to debt is simply the present value of this opportunity cost saving. ${ }^{11}$

It should also be noted that the APV approach does not require the assumption that all future debt levels are known. If they are subject to some uncertainty, $D_{N-1}$ in (8) can simply be replaced by the certainty-equivalent debt level. More generally, if the debt itself is subject to default risk, Sick (1988) has shown that the numerator of the second set of terms in (8) can be replaced with the certainty-equivalent interest payments on the risky debt. Alternatively, if we assume a constant debt-to-value ratio, as in Miles and Ezzell (1980) or Myers and Ruback (1988), future debt tax shields take on the risk characteristics of the firm as a whole. While the APV method is often associated with the assumption of riskless interest tax shields, then, the basic approach can easily accommodate more general assumptions. 


\section{Ihe Adiusted Discount Rate Approach}

The Adjusted Discount Rate method seeks a discount rate, $r^{*}$, such that, at any time t,

$$
v_{t}=\sum_{n=1+1}^{N} \frac{c_{n}}{\left(1+r^{*}\right)^{n}}
$$

The specific form of $r^{*}$ depends on what assumption we make about the time pattern and risk of future debt tax shields.

We can derive one ADR expression for the overall cost of capital by first writing (7) as

$$
V_{N-1}=\frac{G_{N}}{1+r}+\frac{r_{f E} G_{L} D_{N-1}}{1+r_{f E}}
$$

If we further assume, as Miles and Ezzell did, that the ratio of debt to firm value is a constant, (D/V), we can express (12) as

$$
V_{N-1}=\frac{C_{N}}{\frac{(1+r)\left(1+r_{f E}\left(1-G_{L}\left(\frac{D}{V}\right)\right)\right.}{\left(1+r_{f E}\right)}}
$$

We can then iterate backward. For example, $V_{\mathrm{N}-2}$ is equal to the sum of the values as of time $N-2$ of three terms: $C_{N-1}$, the net tax advantage of interest paid at time $N-1$, and $V_{N-1}$. This raises the question, however, of what discount rate to apply to $V_{N-1}$. Under 
the Miles and Ezzell argument, the unlevered cost of capital, r, should be used, in which case backward iteration of (13) yields, for any time t:

$$
V_{t}=\sum_{n=t+1}^{N} \frac{C_{n}}{\left[\frac{(1+r)\left(1+r_{f E}\left(1-G_{L}(D / V)\right)\right)}{\left(1+r_{f E}\right)}\right]^{n}}
$$

The expression in square brackets in the denominator plays the role of one plus the adjusted discount rate. Setting the term in square brackets equal to $\left(1+r^{*}\right)$ and solving for $r^{*}$ gives:

$$
r^{*}=r-r_{f E} G_{L}\left(\frac{D}{V}\right)\left(\frac{1+r}{1+r_{f E}}\right)
$$

which is the analogue to Miles and Ezzell's cost of capital expression, generalized to include both corporate and personal taxes. Note that, as in the APV approach discussed above, it is the risk-free equity rate, not the risk-free debt rate that appears in the expression.

The preceding analysis, which is summarized in Equations (D1) and (D3) of Table II, is based on the assumption that the nearest interest tax shield is risk-free while all other fulure tax shields are risky. A second formulation for $r^{*}$ can be derived if we assume instead that all future interest tax shields are risk-free. As in the regime that includes only corporate taxes, there is no general Adjusted Discount Rate expression that is applicable for finite asset lives under this assumption alone. However, if we add the assumption that the operating cash flow stream is a level perpetuity, the Adjusted Present Value expression in (9) reduces to Equation (B1) in Table II. Equation (B1) can in turn be solved to yield the Adjusted Discount Rate formula in Equation (B3) which is 
the analogue to the MM formula (A3) when personal as well as corporate taxes are relevant.

A third formulation for $r^{*}$ results if we go to the opposite extreme and assume that all future interest tax shields, including the nearest one, are risky. In this case, the second term in (12) is discounted at $r$, rather than $r_{f E}$, and the backward iteration process results in Equations (F1) and (F3) in Table II. ${ }^{12}$ Myers and Ruback (1988) use a continuous capital structure rebalancing assumption to justify discounting all interest tax shields at $r$, and they derive an adjusted discount rate that is algebraically equivalent to (F3). Sick (1988) has also shown that (F3) is the limiting case of (D3) as we move to continuous-time discounting.

Finally, we can derive a fourth formulation for $r^{*}$ by starting with a riskadjusted discount version of (4):

$$
E_{N-1}=\frac{C_{N}-r_{f D}\left(1-T_{C}\right) D_{N-1}-D_{N-1}}{1+r_{E}}
$$

Multiplying through by $\left(1+r_{E}\right)$ and solving for $V_{N-1}=E_{N-1}+D_{n-1}$ gives

$$
v_{N-1}=\frac{G_{N}}{1+r_{E}\left(\frac{E_{N-1}}{V_{N-1}}\right)+r_{f D}\left(1-T_{C}\right)\left(\frac{D_{N-1}}{V_{N-1}}\right)} .
$$

If the financing ratios are constant, we can iterate backward in similar fashion to obtain the value of the firm at any time $t$ :

$$
v_{t}=\sum_{n=1+1}^{N} \frac{C_{n}}{\left(1+r_{E} \frac{E}{v}+r_{f D}\left(1-T_{c}\right) \frac{D}{V}\right)^{n}} .
$$


This shows that the weighted average cost of capital is still a valid risk-adjusted discount rate when there are both corporate and personal taxes. Furthermore, the development of (18) did not rest on any specific assumption about the risk of interest tax shields, and hence it is consistent with any of the three assumptions made above. The weighted average cost of capital thus appears in each of Panels B, D and F in Table II (see (B2), (D2) and (F2)).

D. The Flows to Equity Approach

An estimate of the cost of equity is needed to implement the Flows to Equity method. The relationship between the levered and unlevered cost of equity in turn depends on the valuation of the interest tax shields. Hence, each of the three assumptions used in the preceding section leads to a different relationship. The three relationships are found by setting (B2) equal to (B3), (D2) equal to (D3) and (F2) equal to (F3), respectively, and solving for ${ }^{C} E$. The resulting expressions are shown in Table II as (B4), (D4) and (F4). ${ }^{13}$ In general, the less risky the interest tax shields are perceived to be by investors, the smaller is the required premium for financial leverage and the less steeply sloped is the relationship between $r_{E}$ and (D/E). Hence Equation (B4) has the flattest slope and (F4) the steepest.

Alternatively, the cost of equity could be estimated using the CAPM, as in (B5), (D5) and (F5). It is important to note, however, that an after-tax CAPM must be used, not the pre-tax CAPM that appears in (A5), (C5) and (E5). This is because all of the valuation relationships, starting with (5), are based on investor cash flows and rates of return after all taxes. Writing the after-tax CAPM equation for a levered firm $\left(r_{E}=r_{f E}+\beta_{L}\left(r_{m}-r_{f E}\right)\right)$ and an unlevered firm $\left(r=r_{f E}+\beta_{U}\left(r_{m}-r_{f E}\right)\right)$, and substituting in (B4), (D4) and (F4), respectively, gives the relationship between levered and unlevered betas for each of the three assumptions about the risk of interest tax shields. These are shown in Equations (B6), (D6) and (F6). As in the relationships 
between $r_{E}$ and $r$, the levered beta increases more steeply with the debt-equity ratio the riskier are the interest tax shields.

\section{E. The Key to Consistent Valuation}

The results of Sections II.B, C and D all lead in the same direction. Starting with any of the three valuation methods, we branch out into Panels $B, D$ or $F$ depending on whether future debt tax shields are assumed to be (1) riskless in perpetuity, (2) risky after the first future period, or (3) risky for all future periods. Given the tax regime, the choice of one of these three assumptions fixes the relationships between the unlevered cost of capital, $r$, the overall cost of capital, $r$, and the cost of equity, $r_{E}$. Hence, each of the three valuation methods will produce identical results as long as we use cost of capital expressions from a given panel in Table II. If expressions from different panels are used simultaneously, on the other hand, these will embody conflicting assumptions about (1) the tax regime and (2) the time pattern and riskiness of future debt tax shields. In that event, inconsistent valuations will arise.

\section{F. A Numerical Example}

The assumed parameter values in Table III can be used to construct a numerical example. The valuation horizon in this example is limited to 10 periods, and both corporate and personal taxes are assumed to affect corporate valuation.

Suppose we assume that the Miles-Ezzell (1980) analysis best reflects the riskiness of interest tax shields. In that case, the set of equations in Panel D of Table II should be used. Using Equation (D3), $r^{*}=.1408$. Discounting 10 periods worth of after-corporate-tax operating cash flows at this rate then gives an estimate of total firm value of 520.03. Alternatively, (D4) could be used to estimate $r_{E}=.19064$, and when this value of $r_{E}$ is substituted into the weighted average cost of capital (D2), the result is $r^{*}=.1408$. Or if (D6) is used to estimate a levered beta of 1.6533 , (D5) gives an estimate for $r_{E}$ of .19064. Thus, the cost of capital expressions in Panel $D$ give internally consistent results. 
Different approaches to valuation can also be tried. Under the Flows to Equity method, the period-by-period cash flows to the equityholders must be calculated, and this requires a schedule of after-corporate-tax debt service charges. If the Adjusted Discount Rate approach is used to calculate a period-by-period schedule of firm values, as in column (2) of Table IV, each period t's debt is just .4V $\mathrm{V}_{\mathrm{t}}$, as shown in column (3). Given $r_{f D}$ and $T_{c}$, the after-tax debt service can be calculated as in column (4), and this gives the cash flows to equityholders shown in column (5). Discounting the flows in column (5) at $r_{E}=.19064$ gives an estimate of the firm's initial equity value of 312.01. Adding this to the initial debt value of 208.01 then gives and estimate of total firm value at time 0 of $\mathbf{5 2 0 . 0 2}$

Finally, the Adjusted Present Value approach, as embodied in Equation (D1), could have been used. This requires a schedule of effective interest tax shields $\left(r_{f E} G_{L} D_{t}\right)$, as calculated in column (6) of Table IV. Then, iterating backward using Equation (D1) successively, the time 0 value of the firm is estimated to be 520.03 . Hence the three major approaches to valuation also give consistent results, as long as they are implemented using consistent cost of capital expressions and consistent assumptions about the time pattern of outstanding debt.

\section{G. Soecial Cases}

The preceding discussion shows how the analyst can achieve consistent valuation by choosing the appropriate panel in Table II and working within that panel. It does not, unfortunately, say how the appropriate panel should be chosen, nor how the inputs needed to work within that panel should be estimated. It should be relatively easy to determine whether the level perpetuity case of Panels $A$ and $B$ is appropriate, but as Hamada and Scholes (1985) point out, it may not be obvious which of the two tax regimes is the more relevant. Moreover, if personal taxes are included in the analysis, unobservable magnitudes such as the net tax gain to leverage, $G_{L}$, and the risk-free 
equity rate, $r_{f E}$, must be estimated to move from one cost of capital expression to another. ${ }^{14}$

Two special cases, which allow these implementation problems to be avoided, are worth noting. The first of these occurs when all debt tax shields are discounted at $r$ (Panels $E$ and $F$ of Table II) and the firm adopts a capital structure characterized by $(E / V)=\beta_{U}$ and $(D / V)=\left(1-\beta_{U}\right)$. In that event, Myers and Ruback (1988) have shown that when a cost of equity, calculated from (E5) and (E6) or from (F5) and (F6), is substituted into the weighted average cost of capital (E2 or F2), the result is:

$$
r^{*}=r_{f D}\left(1-\beta_{U}\right)\left(1-T_{c}\right)+\beta_{U} r_{m} .
$$

The important point to note is that, with the assumed capital structure, the overall cost of capital is the same, regardless of which tax regime holds true. Thus (19) can provide a useful cost of capital expression when the analyst is uncertain as to which tax regime more accurately reflects the reality of the corporate and personal tax codes.

The second special case anises when all cash flows are riskless. Ruback (1986) has shown under very general conditions that the market value of a set of riskless cash flows received by a corporation is equal to the present value of the after-corporate-tax cash flow stream discounted at the after-corporate-tax riskless interest rate. This follows by an arbitrage argument from the observation that such a stream can support 100 percent of its own value in debt financing. That the current results are consistent with this analysis can be seen from Table II. In the case in which there are only corporate taxes, an all-equity-financed riskless cash flow stream would have an unlevered cost of capital $r=r_{f D}$. When $(D / N)=1$, then, all of the expressions for $r^{*}$ $(A 2, A 3, C 2, C 3, E 2, E 3)$ reduce to $r^{*}=r_{f D}\left(1-T_{c}\right)$. When there are both corporate and personal taxes, $r=r_{f E}$ for a riskless, unlevered stream, and when $(D N)=1$, 
Equations (B3), (D3) and (F3) reduce to $r^{*}=r_{f E}\left(1-G_{L}\right)$, while Equations (B2), (D2) and $(F 2)$ reduce to $r^{*}=r_{f D}\left(1-T_{C}\right)$. However, from (1) and the definition of $G_{L}$. $r_{f E}\left(1-G_{L}\right)=r_{f D}\left(1-T_{C}\right)$. Hence, all of the cases treated in Table II collapse to the same overall cost of capital when cash flows are riskless.

\section{Summary and Conclusions}

This paper has attempted to unify some disparate strands from the corporate valuation and cost of capital literature. That literature has proposed several different approaches to valuation, has wrestled with the issue of how best to account for taxinduced interactions between financing and investment and has analyzed the distinctions between the perpetuity and finite-life cases. However, the different approaches and different cases have not all been considered simultaneously in an environment that allows for different tax rates on corporate income, personal income from bonds and personal income from equity.

When these approaches to corporate valuation are analyzed with an eye toward the conditions necessary to ensure consistency among them, the following conclusions emerge:

1. Many of the valuation and cost of capital expressions that have appeared in the literature differ along two dimensions. The first of these is the assumed tax regime, and the second is the assumed time pattern and riskiness of future interest tax shields.

2. Once the analyst has chosen these two assumptions, the cost of capital expressions within any given panel of Table II, used in conjunction with any of the three basic valuation methods, will yield identical estimates of firm value. Mixing expressions across panels, however, implies inconsistent assumptions about the tax regime or the riskiness of interest tax shields and will not yield internally consistent results.

3. If one moves horizontally in Table II, from a tax regime that allows for only corporate taxes to one that includes both corporate and personal taxes, the analogous 
valuation and cost of capital expressions differ in two ways. First, $T_{c}$, the corporate tax rate, is replaced by $G_{L}$, the net tax advantage to corporate debt. Second, $r_{f D}$, the riskfree debt rate, is replaced by $r_{f E}$, the risk-free equity rate. ${ }^{15}$ In particular, this implies that an after-tax CAPM must be used in conjunction with any adjusted beta expression (such as B6, D6, F6) when personal taxes are relevant.

4. The weighted average cost of capital is robust to changes in both the tax regime and in the perceived risk of interest tax shields. This is because the relationship between the levered cost of equity, $r_{E}$, and the unlevered cost, $r$, changes to reflect both tax factors and tax shield risk, leaving the weighted average formula intact. To correctly estimate the weighted average starting from scratch, however, the analyst must use the correct relationship between $r$ and $r_{E}$. A special case of the weighted average cost of capital, proposed by Myers and Ruback (1988), does not require specific knowledge of the relationship between $r$ and $r_{E}$, but does require a specific capital structure assumption. 
Table I

Summary of Notation

$$
\begin{aligned}
& \text { E } \quad=\text { market value of equity } \\
& \text { D = market value of debt } \\
& V=E+D=\text { total market value of firm } \\
& r_{m}=\text { equilibrium expected return on market portfolio of equity securities } \\
& r_{E} \quad=\text { cost of equity for an individual firm } \\
& r_{I E}=\text { cost of risk-free equity } \\
& r_{I D}=\text { cost of risk-free debt } \\
& r=\text { unlevered, or all-equity, cost of capital } \\
& r \text { - adjusted, or overall, cost of capital } \\
& T_{p} \quad=\text { personal tax rate on income from bonds } \\
& T_{p E}=\text { effective personal tax rate on income from equity } \\
& T_{c}=\text { corporate tax rate } \\
& G=\left[1-\frac{\left(1-T_{c}\right)\left(1-T_{p E}\right)}{\left(1-T_{p}\right)}\right]=\text { effective tax advantage of corporate debt } \\
& C_{n} \quad=\text { expected value of period } n \text { after-corporate-tax operating cash flow, } \tilde{C}_{n} \\
& C E Q_{n}=\text { certainty-equivalent of } \tilde{C}_{n} \\
& \text { Bu = beta, or systematic risk, of an unlevered firm } \\
& \beta_{L} \quad=\text { beta of otherwise equivalent levered firm }
\end{aligned}
$$


Table II

Summary of Cost of Capital Expressions

Each panel is based on a different set of assumptions about

(1) the tax regime and (2) the time pattern and riskiness of debt tax shields

Panel A: Perpetuity Case; Corporate Taxes Only; Debt Tax Shields Certain
(A1) $V=\frac{C}{r}+T_{c} D$
(B1) $V=\frac{C}{r}+G_{L} D$
(A2) $r^{*}=r_{E}\left(\frac{E}{V}\right)+r_{f D}\left(1-T_{c}\right)\left(\frac{D}{V}\right)$
(B2) $r^{*}=r_{E}\left(\frac{E}{V}\right)+r_{f D}\left(1-T_{c}\right)\left(\frac{D}{V}\right)$
(A3) $r^{*}=r\left(1-T_{c}\left(\frac{D}{V}\right)\right.$
(B3) $r^{*}=r\left(1-G_{L}\left(\frac{D}{V}\right)\right)$
(A4) $r_{E}=r+\left(r-r_{f D}\right)\left(1-T_{c}\right) \frac{D}{E}$
(B4) $r_{E}=r+\left(r-r_{f E}\right)\left(1-G_{L}\right) \frac{D}{E}$
(A5) $r_{E}=r_{f D}+\beta\left(r_{m}-r_{f D}\right)$
(B5) $r_{E}=r_{f E}+\beta\left(r_{m}-r_{f E}\right)$
(A6) $\beta_{L}=\beta_{U}\left(1+\left(1-T_{C}\right) \frac{D}{E}\right)$
(B6) $\beta_{L}=\beta_{U}\left(1+\left(1-G_{L}\right) \frac{D}{E}\right)$

Panel C: Finite or Perpetual Life: Corporate Taxes Only; First Debt Tax Shield Certain, Others Uncertain

(C1) $v_{t}=\frac{c+v_{t+1}}{1+r}+\frac{r_{f D^{T}}\left(\frac{D}{V}\right) v_{t}}{\left(1+r_{f D}\right)}$

(C2) $r^{*}=r_{E}\left(\frac{E}{V}\right)+r_{f D}\left(1-T_{c}\right)\left(\frac{D}{V}\right)$

(C3) $r^{*}=r-r_{f D^{\top}} c\left(\frac{1+r}{1+r_{f D}}\right)\left(\frac{D}{V}\right)$

(C4) $r_{E}=r+\left[r-r_{f D}\left(1+T_{c}\left(\frac{r-r_{f D}}{1+r_{f D}}\right)\right] \frac{D}{E}\right.$

(C5) $r_{E}=r_{f D}+\beta\left(r_{m}-r_{f D}\right)$

(C6) $\beta_{L}=\beta_{U}\left(1+\frac{D}{E}\right)\left(\frac{1+r_{f D}\left(1-T_{c} \frac{D}{V}\right)}{1+r_{f D}}\right)$
(D5) $r_{E}=r_{f E}+\beta\left(r_{m}-r_{f E}\right)$

Panel D: Finite or Perpetual Life; Corporate and Personal Taxes; First Debt Tax Shield Certain; Others Uncertain

(D1)

$$
v_{t}=\frac{c+v_{t+1}}{1+r}+\frac{r_{f E} G_{L}\left(\frac{D}{V}\right) v_{t}}{1+r_{f E}}
$$

(D2) $r^{*}=r_{E}\left(\frac{Q}{V}\right)+r_{f D}\left(1-T_{c}\right)\left(\frac{D}{V}\right)$

(D3) $r^{*}=r-r_{f E} G_{L}\left(\frac{1+r}{1+r_{f E}}\right)\left(\frac{D}{v}\right)$

(D4) $r_{E}=r+\left[r-r_{f E}\left(1+G_{L}\left(\frac{r-r_{f}}{1+r_{f E}}\right)\right] \frac{D}{E}\right.$

(D6) $\beta_{L}=\beta_{U}\left(1+\frac{D}{E}\right)\left(\frac{1+r_{f E}\left(1-G_{L} \frac{D}{V}\right)}{1+r_{f E}}\right)$ 
Panel E: Finite or Perpetual Life;

Corporate Taxes Only; All Debt Tax Shields Uncertain

(E1) $v_{t}=\frac{C+r_{f D} T_{c}\left(\frac{D}{V}\right) v_{t}+v_{t+1}}{1+r}$

(E2) $r^{*}=r_{E}\left(\frac{E}{V}\right)+r_{f D}\left(1-T_{C}\right)\left(\frac{D}{V}\right)$

(E3) $r^{*}=r-r_{f D} T_{c}\left(\frac{D}{V}\right)$

(E4) $r_{E}=r+\left(r-r_{f D}\right) \frac{D}{E}$

(E5) $r_{E}=r_{f D}+\beta\left(r_{m} \cdot r_{f D}\right)$

(E6) $\beta_{L}=\beta_{U}\left(1+\frac{D}{E}\right)$
Panel F: Finite or Perpetual Life; Corporate and Personal Taxes; All Debt Tax Shields Uncertain

(F1) $V_{t}=\frac{C+r_{f E} G_{L}\left(\frac{D}{V}\right) V_{t}+V_{t+1}}{1+r}$

(F2) $r^{*}=r_{E}\left(\frac{E}{V}\right)+r_{f D}\left(1-T_{c}\right)\left(\frac{D}{V}\right)$

(F3) $r^{*}=r-r_{f E} G_{L}\left(\frac{D}{V}\right)$

(F4) $r_{E}=r+\left(r-r_{f E}\right) \frac{D}{E}$

(F5) $r_{E}=r_{f E}+\beta\left(r_{m}-r_{f E}\right)$

(F6) $\beta_{L}=\beta_{U}\left(1+\frac{D}{E}\right)$ 


\section{Table III}

\section{Numerical Example}

Based on assumed parameter values, the equations in Panel D, Table II, are used to show that all valuation methods produce identical results

A. Assumed Parameter Values

$$
\begin{array}{ll}
N=10 \text { periods } & r_{f D}=.10 \\
C=100 & r_{m}=.15 \\
T_{p}=.28 & \beta_{U}=1.0 \\
T_{P E}=.18 & D / V=0.4 \\
T_{c}=.34 &
\end{array}
$$

B. Derived Values

$$
\begin{aligned}
& G_{L}=.2483, \text { from definition in Table I } \\
& r \quad=.15, \text { from (D5)) } \\
& r_{f E}=.0878 \text {, from (1) } \\
& r^{*}=.1408 \text {, from (D3) or from (D2), if (D4) is used to estimate } r_{E} \\
& V \quad=520.03 \text {, from discounting } C_{n} \text { at } r^{*} \\
& \beta_{L}=1.6533 \text {, from (D6)) } \\
& r_{E}=.1906, \text { from (D4) or from (D5) } \\
& E \quad=312.01 \text {, from discounting equity cash flows at } r_{E}
\end{aligned}
$$


Table IV

Numerical Example:

Period-by-Period Schedule of Value and Debt

Based on the assumed parameter values from Table III, period-by-period firm values are derived by discounting the remaining operating cash flows at the overall cost of capital. The debt ratio is 40 percent in each period.

(1)

Period

0

1

2

3

4

5

6

7

8

9

10
(2)

Firm Value Debt

$520.03 \quad 208.01$

$493.24 \quad 197.30$

$462.68 \quad 185.07$

$427.81 \quad 171.12$

$388.04 \quad 155.22$

$342.67 \quad 137.07$

$290.91 \quad 116.36$

231.86

92.74

65.80

35.06

87.66

35.06

(4)

A.T. Debt

Service

24.44

25.25

26.16

27.20

28.39

29.75

31.30

33.07

35.08

37.38
(5)

Equity Cash Effective

Flow Tax Shield
(6)
75.56

74.75

73.84

72.80

71.61

70.25

68.70

66.94

64.92

62.62
4.54

4.30

4.04

3.73

3.38

2.99

2.54

2.02

1.43

0.76 


\section{Footnotes}

1. Nearly all of the cost of capital expressions in this paper have been derived elsewhere, so the primary aim is to synthesize existing results rather than derive new ones. See Ashton and Atkins (1978), Conine (1980), Hamada (1969), Miles and Ezzell (1980,1985), Modigliani and Miller (1963). Myers (1974) and Taggart (1977) for the case in which there are corporate but no personal taxes. Brealey and Myers (1988), Chambers, Harris and Pringle (1982), Ezzell and Kelly (1984), Hamada and Scholes (1985), Lewellen and Emery (1986), Myers and Ruback (1988), Sick (1988) and Yagil (1982) consider the case in which there are both corporate and personal taxes, but don't analyze consistency conditions among all the different valuation methods considered here. The approach in the current paper most closely resembles that of Sick $(1988)$.

2. $C_{n}$ represents the expected after-tax cash flow the company would have gotten in period $\boldsymbol{n}$ if it had been entirely equity-financed. Note that financing charges, such as interest or debt repayment, are not deducted from $C_{n}$.

3. For example, the Adjusted Present Value method does not rely on the assumption of constant financing proportions, so it can be easier to implement when the financing mix is changing. APV also offers a relatively straightforward way to take subsidized financing into account. The ADR method is easy to use when the asset to be valued is similar in terms of both business risk and financing characteristics to another asset for which the required rate of return is known. The FTE method is useful when the available cash flow information gives net income figures but doesn't distinguish between cash operating expenses and financing charges. 
4. Not all five listed assumptions are necessary to establish the validity of each expression in Panel A of Table II individually. However, it is necessary to make all five assumptions if each of the expressions is to be valid simultaneously.

5. The reader might object that to retain comparability with the example in Section II.A, the initial condition should be $D=200$, rather than $D / V=.352$. In that event, Equation (C1) can be used, setting $V_{t+1}=V_{t}=V$, to derive $V=537.1$ and $D / V=.372$. Thus the results still differ from the ones obtained using Panel $A$.

6. As in Miller (1977), $T_{p E}$ should be interpreted as an effective tax rate. In actual fact, the pattern of taxable equity income will be determined by the patterns of dividend payments and of gain or loss realizations. $T_{p E}$ is the uniform annual tax rate that would produce tax payments having the same present value as the pattern of actual tax payments on equity income.

7. In a CAPM context, $r_{f E}$ can be thought of as the equilibrium pre-tax return on a zerobeta equity portfolio. Alternatively, one could imagine an entirely equity-financed firm with riskless assets. Such a firm's cost of equity would be $r_{f E}$. For the analysis that follows, it is not necessary that a specific, riskless equity security exist as long as one can be created synthetically.

8. A relatively simple proof can be constructed using the same steps found in Rubinstein (1973), but with end-of-period investor wealth calculated after all taxes.

9. To establish (8), it should be noted that in period N-2 and all prior periods, the expressions for the values of debt and equity take the form 


$$
\begin{aligned}
& D_{N-2}=\frac{\left[r_{f D}\left(1-T_{P}\right) D_{N-2}+D_{N-2}\right]}{1+r_{f E}\left(1-T_{P E}\right)} \text {, and } E_{N-2}= \\
& \frac{\left[\left(C E Q_{N-1}-T_{f D}\left(1-T_{C}\right) D_{N-2}-\left(D_{N-2}-D_{N-1}\right)\right)\left(1-T_{P E}\right)-T_{P E}\left(E_{N-1}-E_{N-2}\right)+E_{N-1}\right]}{1+r_{f E}\left(1-T_{P E}\right)}
\end{aligned}
$$

Simplifying, using (7), and iterating backward yields (8).

10. The assumptions needed to justify multiperiod risk-adjusted discounting are discussed in Fama (1977), Myers and Turnbull (1977) and Sick (1988). They revolve around the nature of the cash flow process over time.

11. In the case considered in most textbooks, in which personal taxes are ignored, $S$ is interpreted as a stream of interest tax shields discounted at the pre-tax debt rate. However, any such expression for $S$ can be written in two ways:

$$
S=\sum_{n=1+1}^{N} \frac{r_{f D} T_{c} D_{n-1}}{\left(1+r_{f D}\right)^{n}}=\sum_{n=1+1}^{N} \frac{\left[r_{f D}-r_{f D}\left(1-T_{c}\right)\right] D_{n-1}}{\left(1+r_{f D}\right)^{n}}
$$

Moreover, if $T_{P}=T_{P E}=0$ in (1), $r_{f D}$ is equal to $r_{f E}$, the required return on risk-free equity. Thus (10) can be thought of as a natural generalization of the case that includes only corporate taxes.

12. For completeness, analogous equations for the case in which there are corporate but no personal taxes are shown in Panel $E$. 
13. Yagil's (1982) expression for the relationship between ${ } E$ and $r$, derived for the case of riskless interest tax shields, is different from (B4), because he defines ${ }^{{ }} E$ in after-personal-tax terms.

14. Empirical studies, such as Masulis' (1983) work on exchange offers, afford one possible avenue for estimating $G_{L}$. High-grade preferred stock might be used to estimate $r_{f E}$, although the picture is clouded by the effect of the intercorporate dividend exclusion. Another possibility is a constructed series of zero-beta equity returns, as in Black and Scholes (1974). Alternatively, equation (1) plus the definition of $G_{L}$ in Table I can be combined to yield $r_{f E}\left(1-G_{L}\right)=r_{f D}\left(1-T_{c}\right)$, which can in turn be used to estimate $r_{\mathrm{fE}}$ if the analyst is willing to rely on an estimate of $G_{L}$.

15. Although not written in that form in Table II, these two rules are also valid for the weight average cost of capital (B2, D2, F2). That is because, as shown in footnote 14 , $r_{f E}\left(1-G_{L}\right)=r_{f D}\left(1-T_{C}\right)$ 
References

D. J. Ashton and D.R. Atkins, "Interactions in Corporate Financing and Investment Decisions: A Further Comment." Journal of Finance 33(December 1978), pp. $1447-53$

Roger P. Bey and J. Markham Collins, "The Relationship Between Before- and After-Tax Yields on Financial Assets." The Financial Review 23 (August 1988), pp. 313331.

Fischer Black and Myron S. Scholes, "The Effects of Dividend Yield and Dividend Policy on Common Stock Prices and Retums." Journal of Financial Econemics 1(May 1974), pp. 1-21.

Richard A. Brealey and Stewart C. Myers, Principles of Corperate Finance (New York: McGraw-Hill), 3rd. ed., 1988.

Michael J. Brennan, "Taxes, Market Valuation and Corporate Financial Policy." National Tax Journal 23(December 1970), pp. 417-427.

Donald R. Chambers, Robert S. Harris and John J. Pringle, "Treatment of Financing Mix in Analyzing Investment Opportunities." Einancial Manacement 11/Summer 1982), pp. $24-41$.

Thomas E. Conine, Jr., "Corporate Debt and Corporate Taxes: An Extension." Jeurnal of. Einance 35(September 1980), pp. 1033-37. 
John R. Ezzell and William A. Kelly, Jr., "An APV Analysis of Capital Budgeting Under Inflation." Einancial Management 13 (Autumn 1984), pp. 49-54.

Eugene Fama, "Risk-Adjusted Discount Rates and Capital Budgeting Under Uncertainty." Journal of Financial Economics 5 (August 1977), pp. 3-24.

Roger H. Gordon and Burton G. Malkiel, "Corporation Finance". In H.J. Aaron and J. A. Pechman, eds. How Taxes Affect Economic Behavior (Washington, D.C.: Brookings Institution), 1981.

Robert S. Hamada, "Portfolio Analysis, Market Equilibrium and Corporation Finance". Journal of Finance 24 (March 1969), pp. 13-31.

Robert S. Hamada and Myron S. Scholes, "Taxes and Corporate Financial Management". In Edward I. Altman and Marti G. Subrahmanyam, eds. Becent Advances in Corporate Einance (Homewood IL: Richard D. Irwin), 1985.

Wilbur G. Lewellen and Douglas R. Emery, "Corporate Debt Management and the Value of the Firm." Journal of Financial and Quantitative Analysis 21 (December 1986), pp. $415-26$.

Ronald W. Masulis, "The Impact of Capital Structure Change on Firm Value: Some Estimates." Journal of Finance 38(March 1983), pp. 107-26.

James Miles and John R. Ezzell, "The Weighted Average Cost of Capital, Perfect Capital Markets and Project Life: A Clarification." Journal of Financial and Quantitative Analysis 15 (September 1980), pp. 719-730. 
"Reformulating Tax Shield Valuation: A Note". Journal of

Einance 40 (December 1985), pp. 1485-92.

Merton H. Miller, "Debt and Taxes." Journal of Finance 32 (May 1977), pp. 261-276.

Franco Modigliani and Merton H. Miller, "Corporate Income Taxes and the Cost of Capital:

A Correction." American_Economic Review 53 (June 1963), pp. 433-443.

Stewart C. Myers, "Interactions of Corporate Financing and Investment Decisions-Implications for Capital Budgeting." Journal of Finance 29 (March 1974), pp. $1-25$.

Stewart C. Myers and Richard S. Ruback, "Discounting Rules for Risky Assets". Harvard Business School Working Paper, November 1988.

Stewart C. Myers and Stuart M. Turnbull, "Capital Budgeting and the Capital Asset Pricing Model: Good News and Bad News." Jeurnal of Finance 32 (May 1977), pp. $321-332$.

Richard S. Ruback, "Calculating the Market Value of Risk-Free Cash Flows." Lournal of Einancjal Economics 15 (March 1986), pp. 323-339.

Mark E. Rubinstein, "A Mean-Variance Synthesis of Corporate Financial Theory." Journal of Finance 28 (March 1973), pp. 167-182. 
Gordon A. Sick, "Tax-Adjusted Discount Rates." University of Calgary Working Paper, 1988

Gordon A. Sick, "A Certainty-Equivalent Approach to Capital Budgeting." Einancial Manaqement 15 (Winter 1986), pp. 23-32.

Robert A. Taggart, Jr., "Capital Budgeting and the Financing Decision: An Exposition." Financial Manacement 6 (Summer 1977), pp. 59-64.

Joseph Yagil, "On Valuation, Beta and the Cost of Equity Capital." Journal of Financial and Quantitative Analysis 17 (September 1982), pp. 441-448. 